\title{
Activated and memory alveolar T-lymphocytes in idiopathic eosinophilic pneumonia
}

\author{
C. Albera, P. Ghio, P. Solidoro, I. Mabritto, L. Marchetti, E. Pozzi
}

Activated and memory alveolar T-lymphocytes in idiopathic eosinophilic pneumonia. $C$. Albera, P. Ghio, P. Solidoro, I. Mabritto, L. Marchetti, E. Pozzi. @ERS Journals Ltd, 1995.

ABSTRACT: To investigate the possible involvement of T-lymphocytes in the immunopathogenesis of idiopathic eosinophilic pneumonia (IEP), we have evaluated the phenotypic characteristics both of peripheral blood and alveolar lymphocytes in six patients with symptomatic IEP, and in 24 healthy nonsmokers as controls, by employing bronchoalveolar lavage (BAL), monoclonal antibodies, and flowcytometry.

In IEP, total and differential cell counts showed a mild alveolitis with an increase of eosinophil percentage and number; the alveolar lymphocyte count was also increased. In BAL, the total number both of CD4+ and CD8+ lymphocytes was significantly raised; CD4+ cells expressed early (CD25) activation antigens. The analysis of CD45R0, CD45RA and CD62 L coexpression in IEP patients, when compared to healthy controls, revealed an accumulation of alveolar CD4+ cells showing phenotypic repertoire usually expressed by memory T-cells (CD45R0+, CD45RA-, CD62L-). CD8+ alveolar lymphocytes did not show any significant increase of activation antigen coexpression. Circulating lymphocytes were not significantly increased and showed only a significantly higher CD25 expression.

These data suggest that a pivotal role is played by activated and memory CD4+ alveolar lymphocytes in IEP patients.

Eur Respir J., 1995, 8, 1281-1285.
Clinical and Biological Sciences Dept, Pulmonary Diseases Division, University of Turin, Italy.

Correspondence: C. Albera Clinical and Biological Sciences Dept Pulmonary Diseases Division University of Turin C/O San Luigi Gonzaga Hospital Regione Gonzole 10 10043 Orbassano (Turin) Italy

Keywords: Activation antigens alveolar lymphocytes bronchoalveolar lavage idiopathic eosinophilic pneumonia memory T-lymphocytes

Received: May 241994 Accepted after revision April 31995
Eosinophilic lung disorders are characterized by the accumulation of eosinophil leucocytes in pulmonary structures (alveolar spaces, interstitium) and, frequently, also in the peripheral blood [1]. In patients with idiopathic eosinophilic pneumonia (IEP), bronchoalveolar lavage (BAL) shows an increase of the total cell count, with a marked increase of eosinophils; the percentage of macrophages is consequently reduced, whereas lymphocytes do not show significant changes [1]. Eosinophilic lung disorders include Loeffler's syndrome [2], Aspergillus infection [3], eosinophilic pneumonia in bronchial asthma [4], drug-induced pneumonia [5], tropical eosinophilia [6], chronic eosinophilic pneumonia [7], acute eosinophilic pneumonia with respiratory failure [8], Churg-Strauss syndrome [9], and idiopathic eosinophilic pneumonia [10].

Mechanisms leading to the parenchymal injury in these diseases are mainly mediated by factors contained in eosinophil granules [11]. Some useful information on the immunopathogenesis of idiopathic eosinophilic lung disease could be obtained by the analysis of processes physiologically involved in eosinophil maturation and traffic. In fact, in normal conditions, lymphocytes, recruited and activated by antigen-presenting cells, release lymphokines, such as interleukin-3 (IL-3) [12] granulocyte/macrophage colony-stimulating factor (GM-CSF)
[13], interleukin-4 (IL-4) [14] and interleukin-5 (IL-5) $[13,15]$, regulating eosinophil differentiation, maturation, proliferation, recruitment and activation [16]. These physiological activities, if upregulated, may have a central role in the modulation of eosinophil-mediated tissue damage within the alveolar microenvironment [17]. On the other hand, the accumulation of eosinophils in the lung, observed in experimental conditions in mice, appears to be lymphocyte-dependent, mast-cell-independent and mainly IL-5 mediated [15]. The aim of this study was to investigate a possible involvement of T-lymphocytes in the pathogenesis of IEP [18], by employing BAL, monoclonal antibodies and flow-cytometry.

\section{Patients and methods}

\section{Study population}

Six symptomatic patients with IEP were studied. They included two males and four females, aged 37-58 yrs (mean \pm sD $43 \pm 9$ yrs, one smoker and five nonsmokers).

Diagnosis, in all patients, was made on the basis of clinical, laboratory and chest radiographic data, and was 
confirmed by histological findings on specimens from transbronchial lung biopsies performed during bronchoscopy, after bronchoalveolar lavage, in the same lung lobe or segment showing radiological abnormalities. Histological analysis showed eosinophilic infiltration of lung parenchyma without vasculitis, fibrosis, granulomas or necrosis; no evident increase of either S100 + or CD1+ cell was found either in tissues or in BAL. No parasitic infestation, exposure to chemicals, concomitant infection, drug intake or abnormal immunoglobulin $\mathrm{E}$ (IgE) levels were present in the population studied. No patient had a medical history of asthma, and pulmonary function tests excluded actual obstruction; in all cases, the disease was symptomatic (fever, cough, dyspnoea); elevation of erythrocyte sedimentation rate and resting hypoxaemia were evident (arterial oxygen tension $\left(\mathrm{Pa}_{\mathrm{a}} \mathrm{O}_{2}\right)<8$ $\mathrm{kPa})$. All patients studied had abnormal chest radiographs, showing peripheral nonsegmental infiltrates. In two patients, the clinical presentation was acute (disease duration 1-4 weeks), and in four it was subacute or chronic (disease duration more than 12 weeks). No patients had received steroids or any other therapy at the time of the study, and all showed a dramatic improvement of clinical signs and symptoms, and of radiological opacities after corticosteroid treatment (prednisone $1 \mathrm{mg} \cdot \mathrm{kg}^{-1}$ q.d. for 2-4 weeks).

As a control group, 24 healthy nonsmokers were studied; this group consisted of 14 males and 10 females, aged $37-58$ yrs (mean \pm sD $56 \pm 14$ yrs).

\section{Cell isolation and preparation}

Bronchoalveolar lavage was performed using the method described previously [19]. Briefly, informed consent was obtained from each subject; after a pretreatment with parental atropine sulphate $(0.5 \mathrm{mg})$, the airways were anaesthetized with $2 \%$ lidocaine. A fibreoptic bronchoscope (Olympus BF-1T10) was advanced and wedged into either the middle lobe (controls) or into the radiologically affected segments or lobes (IEP patients) under direct visualization. Lavage was carried out with 200
$\mathrm{mL}$ of prewarmed $\left(37^{\circ} \mathrm{C}\right)$ sterile saline solution in ten 20 $\mathrm{mL}$ aliquots, with immediate gentle vacuum (syringe) aspiration after each injection. The total amount of fluid recovered was measured (always $>60 \%$ of injected saline); the first aliquot recovered was examined separately for cytological and bacteriological studies, and the rest were pooled. Immediately after lavage, the fluid was filtered though two layers of sterile surgical gauze. Cells were separated from the lavage fluid by centrifugation in a Haeraeus Minifuge-T refrigerated centrifuge $\left(4^{\circ} \mathrm{C}, 20\right.$ min, $900 \mathrm{rpm}$ ) and washed in balanced salt solution (phosphate buffered saline (PBS) Serva). Total cell count and viability evaluation (trypan blue dye exclusion test) were performed on a Bürker haemocytometer; differential cell count was carried out on Diff-Quick (Don Baxter) stained cytospin smears, counting at least 400 cells. Immediately before BAL, peripheral blood samples were obtained from each patient and control subject by venipuncture: $10 \mathrm{~mL}$ vacuum sterile test tubes containing lithium heparin (Vacutainer, BD) were employed. Lymphocytes were separated by centrifugation of blood samples after stratification on density gradient (Lymphoprep, Nyegaard) for $20 \mathrm{~min}$ at $1,000 \mathrm{rpm}$. Simultaneously, haemochromocytometric assay was performed (Technicon Hematology System H3) to evaluate total and differential count of white blood cells.

\section{Phenotypic studies}

Nonadherent cells were obtained by $1 \mathrm{~h}$ incubation at $37^{\circ} \mathrm{C}$ in humidified $5 \% \mathrm{CO}_{2}$ atmosphere (Haeraeus autozero incubator), either from whole cellular BAL pellet or mononuclear cells from peripheral blood, washed twice in PBS and resuspended in sterile RPMI 1640 (Serva) in sterile $250 \mathrm{~mL}$ polystyrene flasks (Falcon). Phenotypic characteristics were evaluated by employing a panel of commercially available monoclonal antibodies (table 1) and flow-cytometry (Facsan, Becton-Dickinson). Standard staining procedure [20] and single or two-colour analysis with Facscan software (Becton-Dickinson) were used (at least 5,000 events were assumed for each sample).

Table 1. - CD, characteristics, specificity, and source of monoclonal antibodies employed

\begin{tabular}{|c|c|c|}
\hline $\mathrm{CD}$ & Commercial & Specificity \\
\hline CD3 & Anti-Leu $4 *$ & Mature T-lymphocytes \\
\hline CD4 & Anti-Leu $3 *$ & Helper-inducer T-lymphocytes \\
\hline CD8 & Anti-Leu $2 *$ & Suppressor-cytotoxic T-lymphocytes \\
\hline CD25 & Anti-IL2R * & p55 IL-2 receptor \\
\hline $\mathrm{CD} 49 \mathrm{a}$ & Anti-VLA-1 \# & $\begin{array}{l}\beta \text {-intergrin; late-activated, not } \\
\text { proliferating T-lymphocytes }\end{array}$ \\
\hline CD45RA & Anti-Leu18* & $\begin{array}{l}\text { Isoform of common leucocyte } \\
\text { antigen; naive T-lymphocytes }\end{array}$ \\
\hline CD45R0 & Anti-UCHL1 * & $\begin{array}{l}\text { Isoform of common leucocyte } \\
\text { antigen; memory T-lymphocytes }\end{array}$ \\
\hline CD62L & $\begin{array}{l}\text { Anti-Leu } 8 * \\
\text { Anti-HLA-DR } *\end{array}$ & L-selectin; adhesion molecule \\
\hline CD45 & Anti-HLe-1 * & Pan-leucocyte \\
\hline CD14 & Anti-LeuM3 * & Monocytes \\
\hline
\end{tabular}

*: Source Becton-Dickinson (Mountain View, CA, USA); \#: source T-Cell Science (Cambride, MA, USA). IL-2: interleukin-2;

VLA-1: very late activation antigen-1; HLA-DR: human leucocyte antigen-DR; MHC: major histocompatibility complex. 
Lymphocyte gates were obtained by using linear forward angle light scatter; the lymphocyte gates were validated by employing CD45-fluorescein-conjugated (pan-leucocyte) and CD14 phycoerythrin-conjugated (monocyte) monoclonal antibodies [20]. The lymphocyte population was defined as CD45bright CD14negative; more than 95\% of all lymphocytes in each sample was contained within the boundaries of the lymphocyte light-scatter gate.

\section{Statistical analysis}

Data are expressed as mean \pm standard error of the mean (SEM): results obtained were analysed by Mann-WhitneyTest. A p-value of less than 0.05 was considered statistically significant.

\section{Results}

All samples from IEP patients showed no growth of Gram-positive or Gram-negative bacteria, mycobacteria, or fungi. More than $95 \%$ of cells recovered were viable in all samples studied. Total and differential cell counts in patients with IEP showed, when compared to healthy controls, a mild alveolitis $\left(2.9 \pm 0.3\right.$ vs $1.8 \pm 0.1 \times 10^{5}$ cells $\left.\cdot \mathrm{mL}^{-1} \mathrm{p}<0.001\right)$, an increase both of eosinophil percentage $(49 \pm 1$ vs $0 \% ; \mathrm{p}<0.001)$ and eosinophil absolute number $\left(141.2 \pm 34.4\right.$ vs $0 \times 10^{3}$ cells $\left.\cdot \mathrm{mL}^{-1} ; \mathrm{p}<0.001\right)$. Neutrophil percentage, as well as total count, showed a mild but significant increase in IEP patients when compared to healthy controls $(3.0 \pm 0.5$ vs $0.9 \pm 0.4 \%$, respectively; $\mathrm{p}<0.008$; and $11.1 \pm 1.6$ vs $1.1 \pm 0.4 \times 10^{3}$ cells $\cdot \mathrm{mL}^{-1}$, respectively; $\mathrm{p}<0.001)$. No significant changes in lymphocyte mean percentage were seen $(9.7 \pm 1.8$ vs $6.7 \pm 1.3 \%$; $\mathrm{p}=\mathrm{NS})$. The absolute number of alveolar lymphocytes was significantly increased, being about three times more than in healthy controls $\left(27.7 \pm 5.1\right.$ vs $10.8 \pm 2.3 \times 10^{3}$ cells $\left.\cdot \mathrm{mL}^{-1} ; \mathrm{p}<0.03\right)$.

CD3+, CD4+ and CD8+ alveolar lymphocytes were evaluated either as a percentage of positive cells or as absolute number of positive cells per millilitre fluid (table 2 ). When data were expressed as percentage of positive cells, CD3+ lymphocytes were higher in healthy controls

Table 2. - Percentage and absolute number of BAL CD3+, CD4+, CD8+ lymphocyte subsets in IEP patients and in control group

\begin{tabular}{cccc}
\hline & $\begin{array}{c}\text { IEP } \\
\text { patients }\end{array}$ & $\begin{array}{l}\text { Healthy } \\
\text { controls }\end{array}$ & p-values \\
\hline CD3+ & & & \\
Cells \% & $83 \pm 1$ & $91 \pm 1$ & $<0.003$ \\
Cells $\times 10^{3} \cdot \mathrm{mL}^{-1}$ & $25.0 \pm 7.5$ & $9.9 \pm 1.8$ & $<0.01$ \\
CD4+ & & & \\
Cells \% & $53 \pm 6$ & $51 \pm 2$ & NS \\
Cells $\times 10^{3} \cdot \mathrm{mL}^{-1}$ & $16.7 \pm 6.8$ & $5.5 \pm 1.0$ & $<0.02$ \\
CD8+ & & & \\
Cells \% & $31 \pm 11$ & $37 \pm 2$ & $\mathrm{NS}$ \\
Cells $\times 10^{3} \cdot \mathrm{mL}^{-1}$ & $8.4 \pm 1.9$ & $4.2 \pm 0.8$ & $<0.04$ \\
CD4/CD8 ratio & $2.1 \pm 0.7$ & $1.5 \pm 0.2$ & $\mathrm{NS}$ \\
\hline
\end{tabular}

Data are presented as percentage of all lymphocytes and as number of positive lymphocytes $\times 10^{3} \cdot \mathrm{mL}^{-1}$ (mean $\left.\pm \mathrm{SEM}\right)$. BAL: bronchoalveolar lavage; IEP: idiopathic eosinophilic pneumonia; Ns: nonsignificant.
Table 3. - Percentage of BAL CD3+, CD4+, and CD8+ lymphocytes expressing HLA-DR, CD25, CD49a, CD45R0, CD45RA, and CD26L in IEP patients and in control group

\begin{tabular}{lccc}
\hline & $\begin{array}{c}\text { IEP } \\
\text { patients }\end{array}$ & $\begin{array}{c}\text { Healthy } \\
\text { controls }\end{array}$ & P-values \\
\hline CD3+/HLA-DR+ & $25 \pm 5$ & $16 \pm 2$ & NS \\
CD4+/CD25+ & $16 \pm 3$ & $3 \pm 1$ & 0.001 \\
CD4+/CD49a+ & $13 \pm 2$ & $7 \pm 2$ & NS \\
CD4+/CD62L+ & $2 \pm 1$ & $3 \pm 0.6$ & NS \\
CD4+/CD62L- & $55 \pm 8$ & $45 \pm 1.9$ & NS \\
CD4+/CD45R0+ & $55 \pm 8$ & $47 \pm 3$ & NS \\
CD4+/CD45RA+ & $2 \pm 1$ & $6 \pm 1$ & NS \\
CD8+/CD25+ & $2 \pm 1$ & $2 \pm 1$ & NS \\
CD8+/CD49a+ & $13 \pm 1$ & $16 \pm 1$ & NS \\
\hline
\end{tabular}

Data are presented as percentage of positive lymphocytes (mean士sem). For abbreviations see legend to table 2.

than in IEP patients, whereas no significant differences of CD4+ and CD8+ subsets were observed. Consequently, no significant changes of the $\mathrm{CD} 4 / \mathrm{CD} 8$ ratio were observed, even in the presence of a slight increase of this ratio in IEP patients. When results were expressed as number of positive cells $\times 10^{3} \cdot \mathrm{mL}^{-1}$ recovery fluid, an increase in CD3+ cells, related to a high number both of CD4+ and CD8+ lymphocytes could be seen in IEP patients

The coexpression of activation antigens were referred and analysed either as percentage of all lymphocytes (table 3) or as absolute count (cells $\times 10^{3} \cdot \mathrm{mL}^{-1}$ recovered fluid) (table 4). When data were expressed as percentage of positive cells of all lymphocytes an increase of CD25 expression on CD4+ lymphocytes was observed (16.1 \pm 2.7 vs $3.3 \pm 1 \%$; $\mathrm{p}<0.001)$. When data were expressed as a number of positive cells $\times 10^{3} \cdot \mathrm{mL}^{-1}$ recovered fluid we found a similar increased coexpression of CD25 on CD4+ lymphocytes $\left(2.8 \pm 0.7\right.$ vs $0.7 \pm 0.4 \times 10^{3}$ cells $\cdot \mathrm{mL}^{-1}$; $\mathrm{p}<0.05)$. CD8+ lymphocytes, on the contrary, did not show significant differences regarding the expression both of CD25 and CD49a activation antigens (percentage and total cell number). The evaluation of coexpression on CD4+ alveolar lymphocytes of CD45R0 and CD45RA (tables 3 and 4) showed the percentage and, in particular,

Table 4. - Absolute number of BAL CD3+, CD4+, and CD8+ lymphocytes expressing HLA-DR, CD25, CD49a, CD45R0, CD45RA, and CD62L in IEP patients and in control group

\begin{tabular}{lccc}
\hline & $\begin{array}{c}\text { IEP } \\
\text { patients }\end{array}$ & $\begin{array}{l}\text { Healthy } \\
\text { controls }\end{array}$ & P-values \\
\hline CD3+/HLA-DR+ & $4 \pm 1.3$ & $2.5 \pm 0.7$ & NS \\
CD4+/CD25+ & $2.8 \pm 0.7$ & $0.7 \pm 0.4$ & $<0.05$ \\
CD4+/CD49a+ & $2.8 \pm 2$ & $1.2 \pm 0.8$ & NS \\
CD4+/CD62L+ & $0.4 \pm 0.3$ & $0.3 \pm 0.1$ & NS \\
CD4+/CD62L- & $15.8 \pm 8.7$ & $4.1 \pm 0.6$ & $<0.02$ \\
CD4+/CD45R0+ & $15.9 \pm 8.6$ & $4.7 \pm 1$ & $<0.03$ \\
CD4+/CD45RA+ & $0.6 \pm 0.3$ & $0.8 \pm 0.2$ & NS \\
CD8+/CD25+ & $0.4 \pm 0.2$ & $0.2 \pm 0.1$ & NS \\
CD8+/CD49a+ & $2.8 \pm 1.2$ & $2.8 \pm 0.1$ & NS \\
\hline
\end{tabular}

Data are presented as number of positive lymphocytes $\times 10^{3}$ $\mathrm{mL}^{-1}$ (mean \pm SEM). For abbreviations see legend to table 2 . 
Table 5. - Absolute number of peripheral blood CD3+, CD4+ and CD8+ lymphocyte subsets in IEP and in control group

\begin{tabular}{lccc}
\hline & $\begin{array}{c}\text { IEP } \\
\text { patients }\end{array}$ & $\begin{array}{l}\text { Healthy } \\
\text { controls }\end{array}$ & p-values \\
\hline CD3+ & $2.1 \pm 0.3$ & $2.1 \pm 0.3$ & NS \\
CD4+ & $1.3 \pm 0.2$ & $1.3 \pm 0.1$ & NS \\
CD8+ & $0.9 \pm 0.1$ & $0.9 \pm 0.1$ & NS \\
CD4/CD8 Ratio & $1.5 \pm 0.1$ & $1.4 \pm 0.1$ & NS \\
\hline
\end{tabular}

Data are presented as number of positive lymphocytes $\times 10^{3} \cdot \mu \mathrm{L}^{-1}$ (mean \pm SEM). For abbreviations see legend to table 2 .

Table 6. - Absolute number of peripherial blood cells CD3+, CD4+ and CD8+ lymphocytes expressing HLRDR, CD25, CD49a, CD45R0, CD46RA and CD62L in IEP patients and in control group

\begin{tabular}{lccc}
\hline & $\begin{array}{c}\text { IEP } \\
\text { patients }\end{array}$ & $\begin{array}{l}\text { Healthy } \\
\text { controls }\end{array}$ & P-values \\
\hline CD3+/HLA-DR+ & $0.12 \pm 0.03$ & $0.07 \pm 0.02$ & NS \\
CD4+/CD25+ & $0.20 \pm 0.05$ & $0.11 \pm 0.01$ & $<0.002$ \\
CD4+/CD49a+ & $0.001 \pm 0.001$ & $0.001 \pm 0.001$ & NS \\
CD4+/CD62L+ & $1.00 \pm 0.10$ & $1.10 \pm 0.20$ & NS \\
CD4+/CD62L- & $0.28 \pm 0.13$ & $0.18 \pm 0.40$ & NS \\
CD4+/CD45R0+ & $0.57 \pm 0.11$ & $0.40 \pm 0.80$ & NS \\
CD4+/CD45RA+ & $0.70 \pm 0.21$ & $0.82 \pm 0.13$ & NS \\
CD8+/CD25+ & $0.01 \pm 0.004$ & $0.02 \pm 0.004$ & NS \\
CD8+/CD49a+ & $0.005 \pm 0.003$ & $0.004 \pm 0.002$ & NS
\end{tabular}

Data are presented as number of positive lymphocytes $\times 10^{3} \cdot \mathrm{uL}^{-1}$ (mean \pm SEM). For abbreviations see legend to table 1 and 2 .

the number $\left(15.9 \pm 8.6\right.$ vs $4.7 \pm 1 \times 10^{5}$ cells $\left.\cdot \mathrm{mL}^{-1} ; \mathrm{p}<0.03\right)$ of memory (CD45R0+) T-cells in IEP was higher than in controls. Both low percentage and number of CD4+/CD45RA+ lymphocytes was observed in patients with IEP. In patients with IEP, an increase of CD4+/CD62Llymphocytes, which was significant when evaluated as absolute cell number $\left(15.8 \pm 8.7\right.$ vs $4.1 \pm 0.6 \times 10^{5}$ cells $\cdot \mathrm{mL}^{-1}$; $\mathrm{p}<0.03$ ), was observed (table 4).

In the peripheral blood of IEP patients, eosinophils were significantly higher than in controls $(3.2 \pm 0.9 \mathrm{vs}$ $0.4 \pm 0.1 \times 10^{3}$ cells $\cdot \mu \mathrm{L}^{-1}$, respectively; $\mathrm{p}<0.006$ ) and only a significant increase of $\mathrm{CD} 4 / \mathrm{CD} 25+$ lymphocytes was observed $\left(0.2 \pm 0.05\right.$ vs $0.11 \pm 0.01 \times 10^{3}$ cells $\left.\cdot \mu \mathrm{L}^{-1} ; \mathrm{p}<0.02\right)$ (table 5-6).

\section{Discussion}

We demonstrated that patients with symptomatic IEP, when compared to healthy nonsmoking subjects, were characterized by an increase in total cells, eosinophils and lymphocytes in BAL fluid. The higher number of alveolar CD3+ cells was related both to CD4+ and CD8+ subsets. The analysis of expression of CD45R0 and CD45RA, the two isoforms of a common leucocyte antigen preferentially expressed, respectively, on primed (via $\mathrm{T}$-cell receptor) and on unprimed T-lymphocytes, and of L-selectin CD62L, which enables T-cells to adhere to a ligand expressed on high endothelium venules (HEV), showed that the alveolitis of IEP patients was characterized by an accumulation of CD4+ lymphocytes expressing a memory phenotypic repertoire (CD45R0+, CD45RA-, CD62L-) [21-23]. In addition, accumulation of CD4+ alveolar lymphocytes showing a phenotypic pattern typical of lymphokine-secreting cell, characterized by the expression of early (CD25) activation antigens, was observed in IEP patients.

In the peripheral blood, only a slight increase of eosinophils was observed, accompanied by a less relevant accumulation of CD4+/CD25+ lymphocytes. These differences may be explained either by the preferential accumulation of different cell populations in different tissues and organs [18], or by the ability of activated eosinophils to act as antigen presenting cells for T-lymphocytes [24], leading to a self-maintaining mechanism of lung eosinophilic inflammation.

A similar increase in CD4+/CD25+ lymphocytes both in BAL and in peripheral blood has been observed [21] in allergic asthma, an eosinophil-mediated airway disease, and the number of alveolar CD4+/CD25+ cells was shown to correlate with the number of eosinophils and the severity of disease [25].

As far as the CD8+ lymphocyte subsets were concerned, there was a significant increase of total number of CD8+ cells, without any significant difference of activation antigen expression, suggesting that suppressor/ cytotoxic T-lymphocytes are not actively involved in immunomodulation of idiopathic eosinophil-mediated lung disease.

In summary, we found in patients with symptomatic idiopathic eosinophilic pneumonia, an accumulation of alveolar CD3+ T-lymphocytes, both of CD4 and CD8+ subsets. The CD4+ helper/inducer T-lymphocytes exhibited the surface antigens typically associated with either activated or memory T-lymphocytes. Both activated and memory T-lymphocyte subsets may be involved in the modulation of eosinophilic inflammation in the alveolar spaces.

\section{References}

1. Olivieri D, Pesci A, Bertorelli G. Bronchoalveolar lavage in chronic eosinophilic pneumonia: analysis of six cases in comparison with other interstitial lung diseases. Respiration 1988; 54 (Suppl. 1): 16-22.

2. Loffler W. Zur differential-diagnosen der Lungeninfilrirungen: Uber fluchtuge Succedaininfiltraten (mit Eosinophilie). Beitr Clin Tuberk 1932; 79: 368-372.

3. Ricketti AJ, Greenberg PA, Mintzer R, Patterson R. Allergic bronchopulmonary aspergillosis. Arch Intern Med 1983; 143: 1553-1557.

4. Scadding JG. Eosinophilic infiltrations of the lung in asthmatics. Proc Roy Soc Med 1971; 64: 381.

5. Schatz M, Wasserman S, Patterson R. Eosinophils and immunologic lung disease. Med Clin North Am 1981; 65: 1055-1071.

6. Neva FA, Ottesen EA. Tropical (filarial) eosinophilia. N Engl J Med 1978; 289: 1129-1131.

7. Jederlinic PJ, Sicilian L, Gaensler EA. Chronic eosinophilic pneumonia: a report of 19 new cases and a review of the literature. Medicine 1988; 67; 154-162.

8. Bochheit J, Nemr E, Rodgers G, Feger T, Yakoub O. 
Acute eosinophilic pneumonia with respiratory failure: a new syndrome? Am Rev Respir Dis 1992; 145: 716-718.

9. Lanham JG, Alkon KB, Pusey CD, Hughes GR. Systemic vasculitis with asthma and eosinophilia: a clinical approach to the Churg-Strauss syndrome. Medicine 1984; 63: 65-81.

10. Mayoc RL, Iozzo RL. The eosinophilic pneumonia. In: Fishman AP, ed. Pulmonary Diseases and Disorders. 1988; pp. 683-698.

11. Gleich GJ, Adolphson CR. Eosinophils. In: Crystal RG, West JB, eds. The Lung: Scientific Foundations. pp. 1991; 581-590.

12. Warren DJ, Moore MAS. Synergism among interleukin1 , interleukin-5 in the production of eosinophils from primitive hemopoietic stem cells. J Immunol 11988; 140: 94-99.

13. Clutterbuck EJ, Hirst EMA. Human interleukin-5 (IL5) regulates the production of eosinophils in human bone marrow cultures: comparison and interaction with IL-1, IL-3, IL-6 and AM-CSF. Blood 1989; 73: 15041512.

14. Schleimer RP, Sterbinsky SA, Kaiser J et al. Interleukin4 induces adherence of human eosinophils and basophils but not neutrophils to endothelium: association with expression of VCAM-1. J Immunol 1992; 148: 10861092.

15. Okudaira H, Nogami M, Matsuzaki G et al. T-celldependent accumulation of eosinophil in the lung and its inhibition by monoclonal anti-interleukin-5. Int Arch Allergy Appl Immunol 1991; 94: 171-173.

16. Kroegel C, Virchow JC Jr, Luttmann W, Walker C, Warner JA. Pulmonary immune cells in health and disease: the eosinophil leucocyte. (Part I). Eur Respir J 1994; 7: 519-543.
17. Kapsenberg ML, Wiereng EA, Bos JD, Jansen HM. Functional subsets of allergen-reactive human CD4+ Tcells. Immunol Today 1991; 12: 392-395.

18. Saltini C, Richeldi L, Holroyd KJ, Du Bois RM, Crystal RG. Lymphocytes. In: Crystal RG, West JB, eds. The Lung: Scientific Foundations. 1991; pp. 459-482.

19. Albera C, Cappia S, Leonardo E, et al. Mycobacterial lung infection and lymphocytes. In: Baggiolini M, Pozzi E, Semenzato G, eds. Neutrophils, Lymphocytes and Lung. 1990; pp. 277-285.

20. Calvelli T, Denny TN, Paxton H, Gelman R, Kagan I. Guideline for flow cytometric immunophenotyping: a report from the National Institute of Allergy and Infectious Diseases; Division of AIDS. Cytometry 1993; 14: 702-715.

21. Facchini A, Mariani AR, Papa S, Mariani E, Vitale M, Manzoli FA. Determination of human lymphocyte subsets in whole blood flow by cytometry. In: Progress in flow cytometry. Reports from FACS users conference. Bologna, 1985; pp. 31-42.

22. Bradley LM, Croft M, Swain SL. T-cell memory: new perspectives. Immunol Today 1993; 14: 197-199.

23. Pircher LJ. Regulation of tissue-selective T-lymphocyte homing receptors during the virgin to memory/effector cells transition in human secondary lymphoid tissues. Am Rev Respir Dis 1993; 148: S47-S54.

24. Kroegel C, Warner JA, Virchow Jr JC, Matthys H. Pulmonary immune cells in health and disease: the eosinophil leucocyte. (Part II). Eur Respir J 1994; 7: 743-760.

25. Walker C, Kaegi MK, Braun MD, Blaser K. Activated T-cells and eosinophilia in bronchoalveolar lavages from subjects with asthma correlated with disease severity. $J$ Allergy Clin Immunol 1991; 89: 958-967. 